during September 3-10. Further details of these awards, which are known as Endeavour prizes, can be obtained from the Assistant Secretary, British Association for the Advancement of Science, Burlington House, Piccadilly, London, W.1.

\section{Society of Public Analysts and Other Analytical Chemists}

THE seventy-eighth annual general meeting of the Society of Public Analysts and Other Analytical Chemists was held on March 7 in the Meeting Room of the Chemical Society, Burlington House, Piccadilly, London, W.1, with the president, Dr. J. K. Nicholls, in the chair. The financial statement and the report of the Council for the past year were submitted and approved. The membership of the Society was reported as being 1,578 - an increase of sixteen since last year. In addition to six ordinary meetings of the Society, there have been sixteen meetings held by its Sections and Groups in the course of the year. At the conclusion of the meeting, the Bernard Dyer Memorial Lecture of the Society was given by the Hon. Sir George Lloyd-Jacob, of the Chancery Division, High Court of Justice. The following officers were elected for the forthcoming year: President, J. R. Nicholls ; Past-Presidents serving on the Council, Lewis Eynon, E. B. Hughes, G. W. Monier-Williams and George Taylor; Vice-Presidents, R. C. Chirnside, D. W. Kent-Jones and Eric Voelcker ; Honorary Treasurer, J. H. Hamence ; Honorary Secretary, K. A. Williams.

Printing, Packaging and Allied Trades Research Association: Exhibition and Conference

The Printing, Packaging and Allied Trades Research Association is holding a conference and exhibition at the University of Leeds during April 1-2, which will be repeated at the Manchester College of Technology during April 3-4; the exhibition will be open to the public on the first day and restricted to members of the Association on the second, and, in addition, there will be an extra day open to the public at Manchester on April 5. The conference will similarly be divided into sessions which will be open on the first day, and restricted to members on the second. The former will consist of two sessions, on "Research and the Printer" and "Technical Progress", respectively, at which a number of papers will be read. The second day will be devoted to a session on "The Application of Research", followed by a "Brains Trust". Further information can be obtained from the Association at Patra House, Randalls Road, Leatherhead, Surrey.

\section{X-Ray Physics: Symposium in London}

A sclence meeting of the Physical Society will be held during May 2-3 in the Department of Physics, Birkbeck College, Malet Street, London, W.C.1. The meeting will be a symposium on "Recent Developments in the Field of X-Ray Physics". Papers will be delivered by the following: Dr. W. A. Wooster (University of Cambridge), J. Dyson (Associated Electrical Industries, Ltd.), K. Das Gupta (University of Liverpool), R. H. Buteux (Birkbeck College, London), Dr. V. E. Cosslett and W. C. Nixon (University of Cambridge), Prof. Kathleen Lonsdale (University College, London), Dr. W. Ehrenberg and A. Franks (Birkbeck College, London). Visitors wishing to attend this meeting should apply to the offices of the Physical Society, 1 Lowther Gardens, Prince Consort Road, London, S.W.7, for further particulars.

\section{The Night Sky in April}

Futc moon occurs on April 10d. 08h. 53m. U.T., and new moon on April 24d. 07h. 27m. The following conjunctions with the moon take place: April 9d. 20h., Saturn $7^{\circ}$ N.; April 12d. 11h., Mars $7^{\circ}$ N. ; April 22d. 16h., Mercury $6^{\circ}$ S.; April 23d. 04h., Venus $6^{\circ} \mathrm{S}$. In addition to these conjunctions with the moon, Mercury is in conjunction with Venus on April 16d. 19h., Mercury being $1 \cdot 3^{\circ} \mathrm{N}$. Mercury is in inferior conjunction with the sun on April 5 and throughout the month is too close to the sun for favourable observation, and Venus also is unfavourably placed for observation in April. Mars rises at 21h. $50 \mathrm{~m} ., 20 \mathrm{~h} .40 \mathrm{~m}$. and $19 \mathrm{~h}$. $15 \mathrm{~m}$. on April 1, 15 and 30 , respectively. The planet is near $\alpha$ Libræ on April 23 and after this date recedes from the star, moving in a westerly direction. Jupiter sets about an hour after the sun on April 1 and is in conjunction with the sun on April 17, after which it becomes a morning star but is too close to the sun for favourable observation. Saturn, a morning star, sets at $6 \mathrm{~h} ., 5 \mathrm{~h}$. and $4 \mathrm{~h}$. on April 1, 15 and 30, respectively, and as its southern declination is very small, it can be easily observed throughout the night and morning hours. Occultations of stars brighter than magnitude 6 are as follows, observations being made at Greenwich : April 2d. 19h. 58.9m., $A$ Gemi. $(D)$; April 7d. 20h. $07.5 \mathrm{~m}$., 75 Leon. $(D), D$ referring to disappearance. The Lyrid meteors can be seen from about April 18 to 24 , and moonlight will not interfere with observations. Summer time begins on April 20.

\section{"Society for Applied Bacteriology: Winter Meeting"}

IN a paragraph published in Nature of February 23, p. 311, dealing with this meeting, reference is made to a paper by Dr. T. Richards, University of Reading, on the use of night blue or victoria blue for the detection of lipolytic activity of bacteria. These dyes are satisfactory at a concentration of $l$ in 15,000 , and poured plates (nutrient agar, $p \mathrm{H} 7 \cdot 8$ ) can be used for isolations from mixed flora and streaked plates for pure culture testing, lipolysis being indicated by a colour change. The temporary inhibition of bacterial growth referred to is of minor significance, and does not detract from the value of the test.

\section{Announcements}

THE fourth technical trade exhibition of materials and equipment used in the paint, varnish and printingink industries, arranged by the London Section of the Oil and Colour Chemists' Association, will be held at the Borough Polytechnic, Borough Road, London, S.E.1, during April 7-9 (2.30-8.30 p.m. each day). Exhibition brochures can be obtained from the honorary secretary, H. C. Wordsall, c/o Plastanol, Ltd., Crabtree Manor Way, Belvedere, Kent.

A symposrum on "Biology as a Career" is to be held in the Heriot-Watt College, Edinburgh, under the auspices of the Institute of Biology on April 10: During the morning session, the chair will be taken by Dr. H. B. Nisbet, principal of the College, and during the afternoon session it will be taken by Dr. E. Hindle, president of the Institute. Discussions will follow the reading of papers. Further information can be obtained from the Secretary, Institute of Biology, Tavistock House South, Tavistock Square, London, W.C.1. 